J. Clin. Chem. Clin. Biochem.

Vol. 17, 1979, pp. 373-377

\title{
Evaluation of Methods for the Estimation of 5-Aminolevulinate Dehydratase for a Broad Range of Lead Concentrations in the Blood of Exposed Workers
}

\author{
By Jadwiga Chmielnicka and Jadwiga A. Szymańska \\ Department of Toxicological Chemistry, Institute of Environmental Research and Bioanalysis, Medical Academy \\ of Lódz, Poland
}

(Received July 31/November $1 /$ December 12,1978 )

\begin{abstract}
Summary: 5-aminolevulinate dehydratase activity was estimated in the blood of 30 lead-exposed workers and 15 control persons, using (I) the method of Tomokuni ((1974) Arch. Environm. Health 29, 274-281) and (II) the European standard method (Berlin \& Schaller (1974) Z. Klin. Chem. Klin. Biochem. 12, 389-390). The lead level in the blood was in the range $0-11.6 \mu \mathrm{mol} / \mathrm{l}$. It was found that the correlation coefficients between the activity of 5 -aminolevulinate dehydratase and the lead level in blood (up to $4.35 \mu \mathrm{mol} / 1$ ) are higher for method I than method II. These two methods only give similar results for the units of 5-aminolevulinate dehydratase activity when the lead concentrations in the blood are low. For higher concentrations of this metal (up to $11.6 \mu \mathrm{mol} / \mathrm{l}$ ), a high correlation was obtained $(\mathrm{r}=-0.80)$ between the 5 -aminolevulinate dehydratase activity ratio (enzyme measured at $\mathrm{pH} 6.8$ /enzyme measured at $\mathrm{pH} 6.0$; method $\mathrm{I}$ ) and lead concentrations in the blood.
\end{abstract}

\section{Bewertung von Methoden zur Bestimmung von S-Aminolävulinatdehydratase bei einem breiten Bereich der Blei- konzentrationen im Blut exponierter Arbeiter}

Zusammenfassung: Die katalytische Aktivität von 5-Aminolävulinatdehydratase im Blut wurde mit der Methode (I) von Tomokuni ((1974) Arch. Environm. Health 29, 274-281) und (II) der Europäischen Standardmethode nach Berlin \& Schaller ((1974) Z. Klin. Chem. Klin. Biochem. 12, 389-390) bei 30 Blei-exponierten Arbeitern und 15 Kontrollpersonen bestimmt. Die Bleikonzentrationen betrugen 0-11,6 $\mu \mathrm{mol} / 1$. Die Korrelationskoeffizienten zwischen 5-Aminolävulinatdehydratase und Bleikonzentration im Blut (bis zu 4,35 $\mu \mathrm{mol} / \mathrm{l}$ ) sind für Methode I höher. Nur für niedrige Bleikonzentrationen im Blut können die mit diesen beiden Methoden ermittelten Werte für 5-Aminolävulinatdehydratase gegeneinander ausgetauscht werden. Für höhere Bleikonzentrationen (bis zu 11,6 $\mu \mathrm{mol} / \mathrm{l}$ ) wurde eine hohe Korrelation $(\mathrm{r}=0,80)$ zwischen dem 5-Aminolävulinatdehydratase-Verhältnis (Messung bei pH 6,8/Messung bei pH 6,0; Methode I) und der Bleikonzentration im Blut erhalten.

\section{Introduction}

With the exception of zinc protoporphyrin, the activity of 5-aminolevulinate dehydratase (EC 4.2.1.24) presently constitutes one of the most sensitive indices of environmental and occupational exposire to lead (1-11).

The method of estimation of 5-aminolevulinate dehydratase activity, proposed by Gibson et al. (12) has been modified by Bonsingore et al. (13) and by Haas et al. (1).

Tomokuni (14) has also modified this method, introducing a new test, i.e. the determination of the 5-aminolevulinate dehydratase activity ratio, based on measurement of the enzyme activity at different pHips. Leąd exposure brings about a change in the $\mathrm{pH}$ optimum for blood 5-aminolevulinate dehydratase, optimal $\mathrm{pH}$ values being equal to 6.0 and 6.8 for occupationally exposed and control persons, respectively.

In 1974, Berlin \& Schaller (15) also elaborated a method, which was proposed as the European standard. In describing their analytical procedure, these authors presented no data on the range of activity of 5-aminolevulinate dehydratase in persons exposed to lead, and its dependence on lead concentration in blood; such data were, however, presented by Tomokuni (14). The two methods use different units: porphobilinogen $[\mu \mathrm{mol} / \mathrm{h} \cdot \mathrm{ml}$ erythrocytes] in the Tomokuni method, and 5 -aminolevulinate $[\mu \mathrm{mol} / \mathrm{min} \cdot 1$ erythrocytes $]$ in the Berlin \& Schaller method. This creates difficulties 
in the comparison of results from different laboratories (9).

The aim of this paper was to analyse the results for the determination of 5-aminolevulinate dehydratase activity by the method of Tomokuni (14) and by the standard European method according to Berlin \& Schaller (15) in the blood of persons occupationally exposed to lead, and for a broad range of blood lead concentrations.

\section{Materials and Methods}

30 workers exposed occupationally to lead and 15 control persons were studied. The activity of 5-aminolevulinate dehydratase was estimated in all these persons by two methods: (I) according to Tomokuni (14) - and (II) according to Berlin \& Schaller (15). The hematocrit (16) and lead level were also estimated. Lead was determined by the dithizone method (17). Dithizone (diphenylthiocarbazone), in combination with lead at $\mathrm{pH} 9.5$, produces a coloured complex of lead dithizone. A sample of mineralized blood $(3-5 \mathrm{ml})$ was added to $5 \mathrm{ml}$ of $250 \mathrm{~g} / \mathrm{l}$ ammonium citrate solution, then mixed. The $\mathrm{pH}$ was adjusted to 9.5 by titrating with ammonium hydroxide. The solution was then added to $5 \mathrm{ml} 100 \mathrm{~g} / \mathrm{l}$ potassium cyanide, together with $1 \mathrm{ml}$ of dithizone solution in chloroform. After shaking for 1 minute the chloroform phase became redviolet. The chloroform phase was adjusted to a volume of $10 \mathrm{ml}$ with pure chloroform. Excess of dithizone was removed by shaking with a solution containing ammonium hydroxide and potassium cyanide. The sample was then filtered through anhydrous sodium sulfate. Absorption was read in a spectrophotometer at $510 \mathrm{~nm}$ in $5 \mathrm{~cm}$ cuvettes against the blank. A standard curve was prepared using animal blood $(0.005$ $\mu \mathrm{mol}-0.029 \mu \mathrm{mol}$ of lead in the sample). Precision of this method was equal to $\pm 9.2 \%$.

\section{Results}

The results presented in figure 1 indicate that after $24 \mathrm{~h}$ the activity of 5-aminolevulinate dehydratase in stored blood decrease by $37.6 \pm 16.8 \%$ when estimated by method II. Taking this into account, all estimations of activity of 5-aminolevulinate dehydratase were performed 3-4 h after blood sampling. During this period, blood was stored at $+2{ }^{\circ} \mathrm{C}$.

Figures $2 a$ and $2 c$ show the dependence of activity of 5-aminolevulinate dehydratase estimated by method I (a) and method II (c) on the blood lead concentrations. For both methods, a non-linear dependence was observed troughout the lead concentration range studied. Linear dependencies were found for appropriate intervals of lead concentrations only. Correlation coefficients and regression equations were calculated for two exemplary ranges of lead concentration in blood up to $1.93 \mu \mathrm{mol} / 1$ blood (tab. 1) and up to $4.35 \mu \mathrm{mol} / 1$ blood (fig. $2 \mathrm{~b}$ and $2 \mathrm{~d}$ ).

The correlation between the activity of 5-aminolevilinate dehydratase, estimated by two methods, and lead concentration in blood, and the corresponding regression equations are presented in figure $3 a$ for the lead concen-

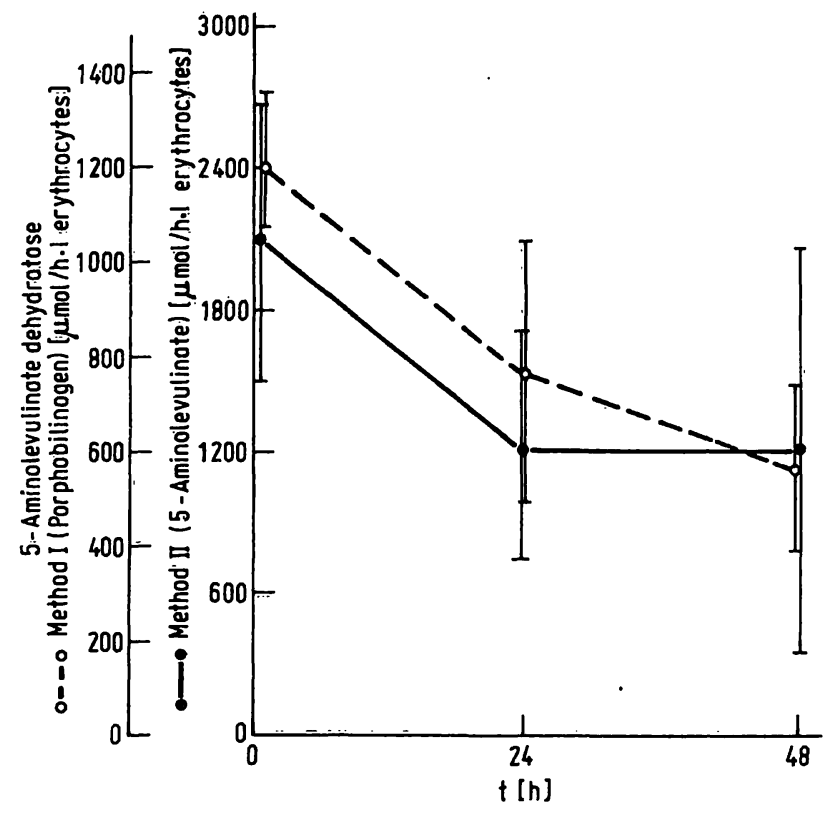

Fig. 1. Relationship between activity of 5-aminolevulinate dehydratase determined by method I $(----)$ and method II $(\longrightarrow)$ and time of blood storage at $+2^{\circ} \cdot \hat{\mathbf{C}}$. Activity curves obtained from five subjects not exposed to lead.

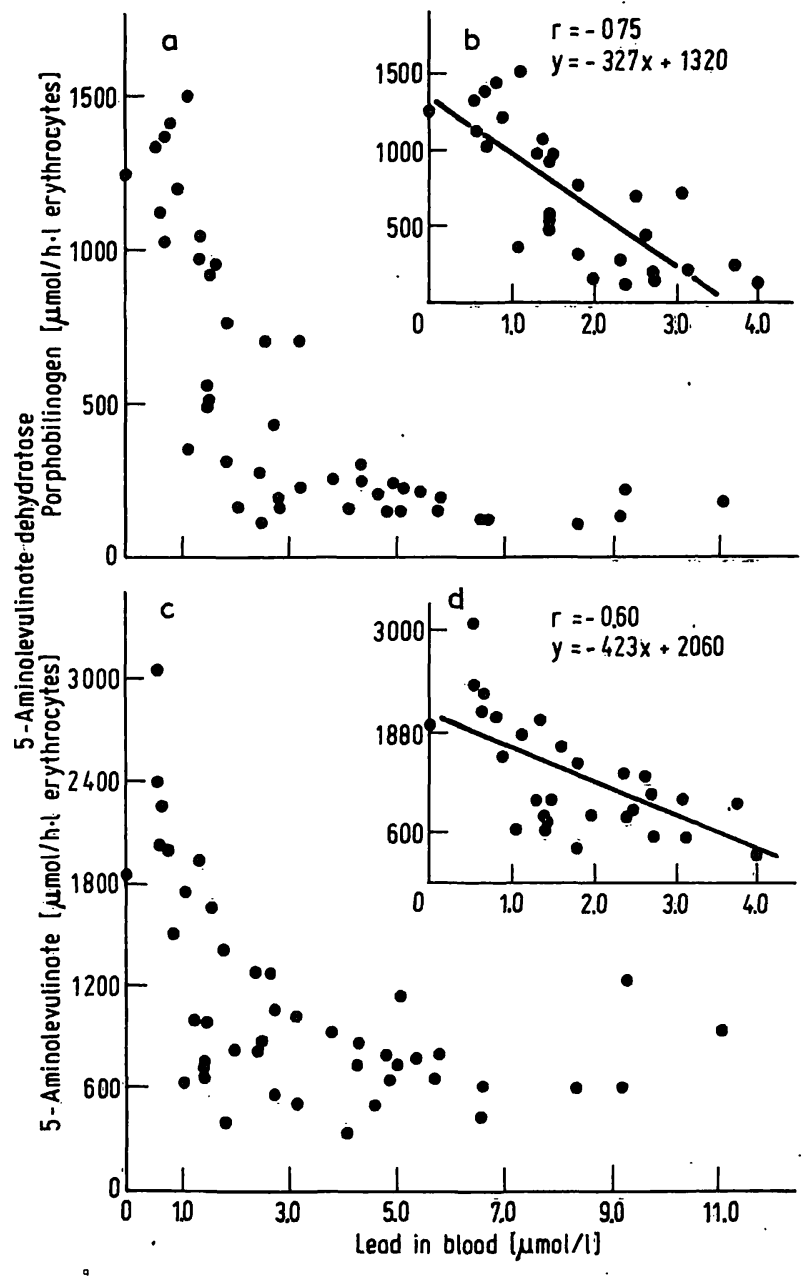

Fig. 2. Correlation between activity of 5-aminolevulinate dêhydratase $(a, b$ determined by method $I$; and $c$, $d$ determined by method II) and lead level in blood. 
Tab. 1. Comparison of correlation coefficients between lead level in blood and erythrocyte activity of 5-aminolevulinate dehydratase and of the 5-aminolevulinate dehydratase activity ratio.

\begin{tabular}{|c|c|c|c|}
\hline \multirow[t]{2}{*}{ Test } & \multirow{2}{*}{$\begin{array}{l}\text { Lead level } \\
\text { in blood. } \\
\text { Range from } \\
\text { zero to } \\
\mu \mathrm{mol} / 1\end{array}$} & \multicolumn{2}{|c|}{ Correlation coefficients $x$} \\
\hline & & method I & method II \\
\hline $\begin{array}{l}\text { Activity of } \\
\text { 5-aminolevulinate } \\
\text { dehydratase }\end{array}$ & $\begin{array}{l}1.93 \\
4.35\end{array}$ & $\begin{array}{l}-0.65 \\
-0.75\end{array}$ & $\begin{array}{l}-0.53 \\
-0.60\end{array}$ \\
\hline $\begin{array}{l}\text { 5-aminolevulinate } \\
\text { dehydratase } \\
\text { activity } \\
\text { ratio } x \text { y }\end{array}$ & $\begin{array}{r}1.93 \\
4.35 \\
6.76 \\
11.60\end{array}$ & $\begin{array}{l}-0.10 \\
-0.53 \\
-0.79 \\
-0.80\end{array}$ & \\
\hline
\end{tabular}

$\mathrm{x} /$ Activity ratio $=\frac{\Delta \mathrm{A} \text { at } \mathrm{pH} 6.8}{\Delta \mathrm{A} \text { at } \mathrm{pH} 6.0}$

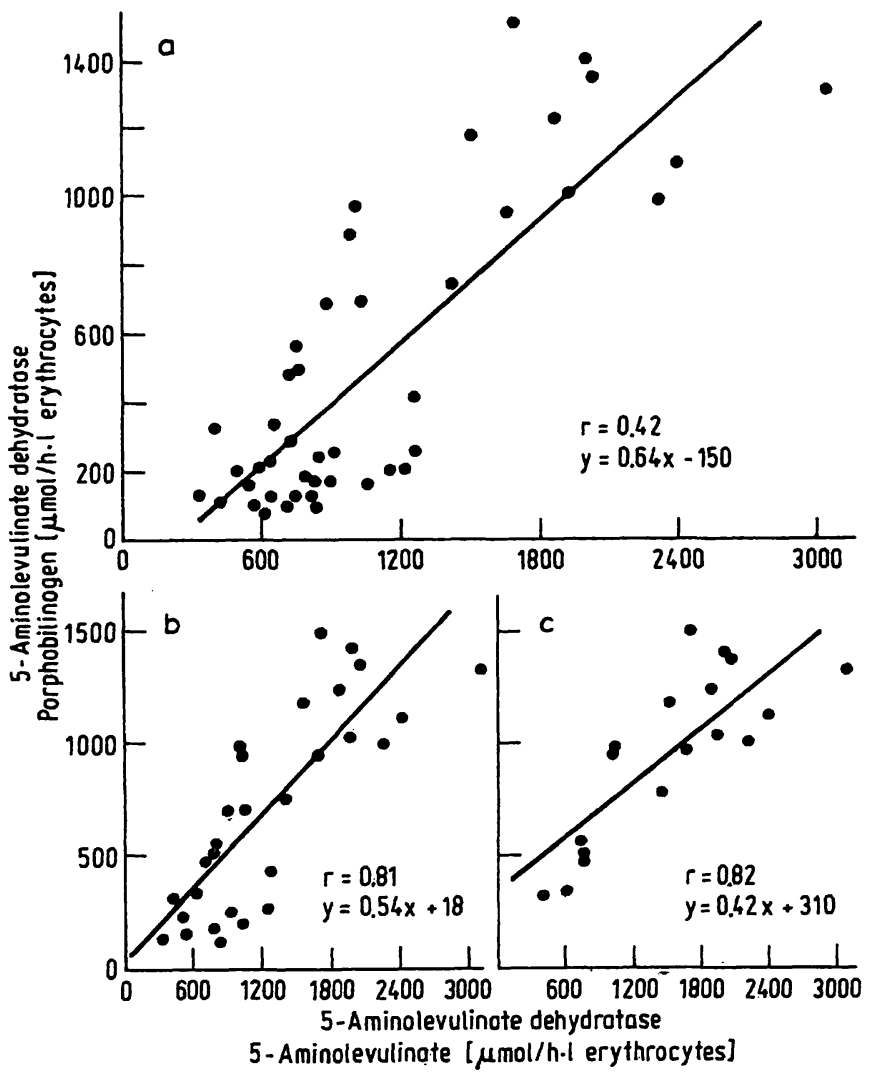

Fig. 3. Correlation between activities of 5-aminolevulinate dehydratase determined by methods I and II for different ranges of lead level in blood: a) up to 11.60 ; b) 4.35 ; c) $1.93 \mu \mathrm{mol} / 1$.

tration range up to $11.60 \mu \mathrm{mol} / 1$ blood $(\mathrm{r}=0.42)$; figure $3 \mathrm{~b}$ shows the data for the lead concentration range up to $4.35 \mu \mathrm{mol} / 1$ blood $(r=0.81)$, and figure $3 \mathrm{c}$ for the lead concentration range up to $1.93 \mu \mathrm{mol} / 1$ blood $(r=0.82)$.

Table 2 presents recalculated values of the units of activity of 5-aminolevilinate dehydratase from method II for comparison with method $\mathrm{I}$, depending on the blood lead concentration.
Tab. 2. Comparison of methods I and II (activity of 5-aminolevulinate dehydratase is expressed in the same units in relation to lead level in blood)

\begin{tabular}{|c|c|c|c|}
\hline \multirow[t]{2}{*}{$\begin{array}{l}\text { Lead level } \\
\text { in blood } \\
{[\mu \mathrm{mol} / 1]}\end{array}$} & \multicolumn{2}{|c|}{$\begin{array}{l}\text { 5-Aminolevulinate dehydratase } \\
\text { (Porphobilinogen) } \\
\text { [ } \mu \mathrm{mol} / \mathrm{h} \cdot[\text { erythrocytes] }\end{array}$} & \multirow[t]{2}{*}{ SD } \\
\hline & I & II & \\
\hline-1.93 & $\begin{array}{l}1 \\
n=18\end{array}$ & $\begin{array}{l}1.58 \\
(1.04-2.29)\end{array}$ & \pm 0.37 \\
\hline $1.93-4.35$ & $\begin{array}{l}1 \\
n=11\end{array}$ & $\begin{array}{l}3.75 \\
(1.24-7.55)\end{array}$ & \pm 1.94 \\
\hline
\end{tabular}

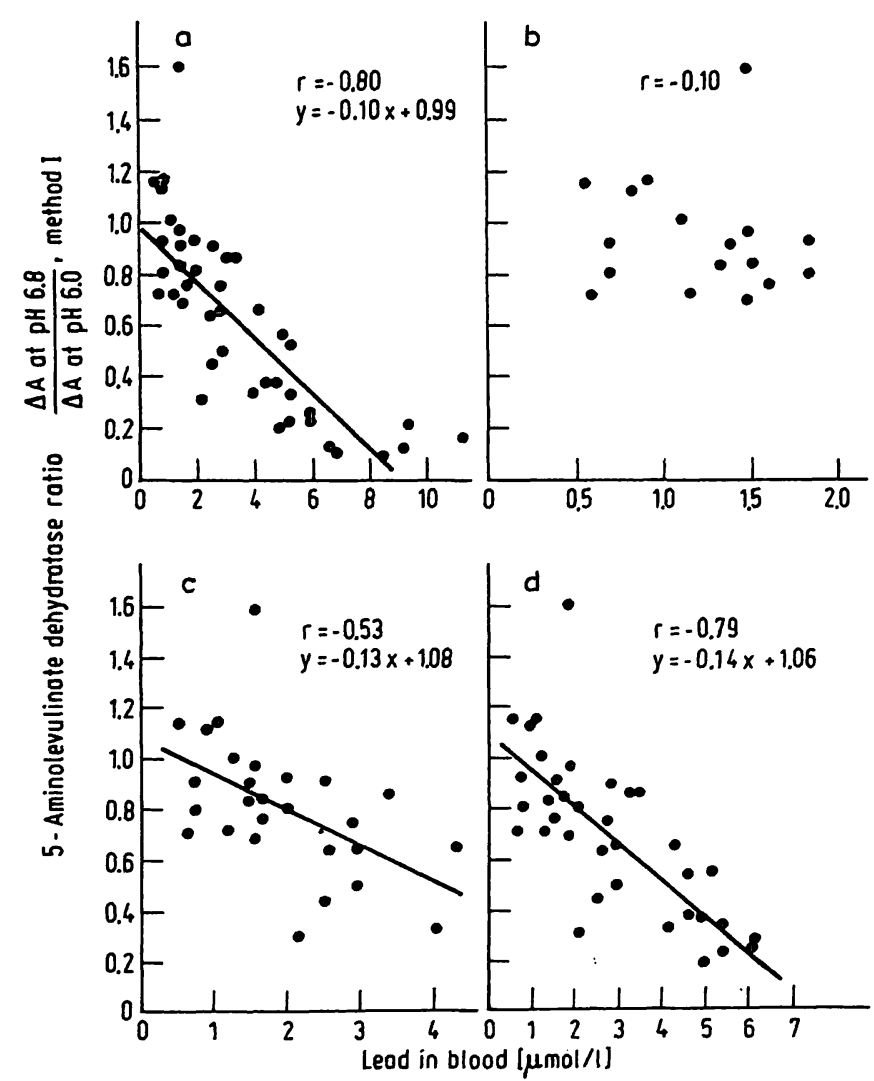

Fig. 4. Relationship between 5-aminolevulinate dehydratase activity ratio (enzyme measured at $\mathrm{pH} 6.8$ /enzyme measured at pH 6.0 ; method I) and lead level in blood: a) up to 11.60 b) up to $1.93 ; \mathrm{c}$ ) up to 4.35 ; d) up to $7.25 \mu \mathrm{mol} / 1$.

Figure 4 displays the dependence of the 5-aminolevulinate dehydratase activity ratio on the lead concentration in blood. For low lead concentrations (up to $1.93 \mu \mathrm{mol} / \mathrm{l}$ blood) there is no correlation (fig. $4 \mathrm{~b}$ ). For higher lead concentrations $r=0.53$ (fig. $4 \mathrm{c}$ ); an identical value was obtained by Tomokuni (14). High lead concentrations yield high correlation coefficients (fig. $4 \mathrm{a}$ and $4 d$ ).

Figure 5 shows frequency distribution of activities of 5 -aminolevulinate dehydratase measured by methods I and II (fig. $5 \mathrm{a}$ and $5 \mathrm{~b}$, respectively). For the control group, the activity of 5-aminolevulinate dehydratase estimated by method I ranged from 710 up to 1500 


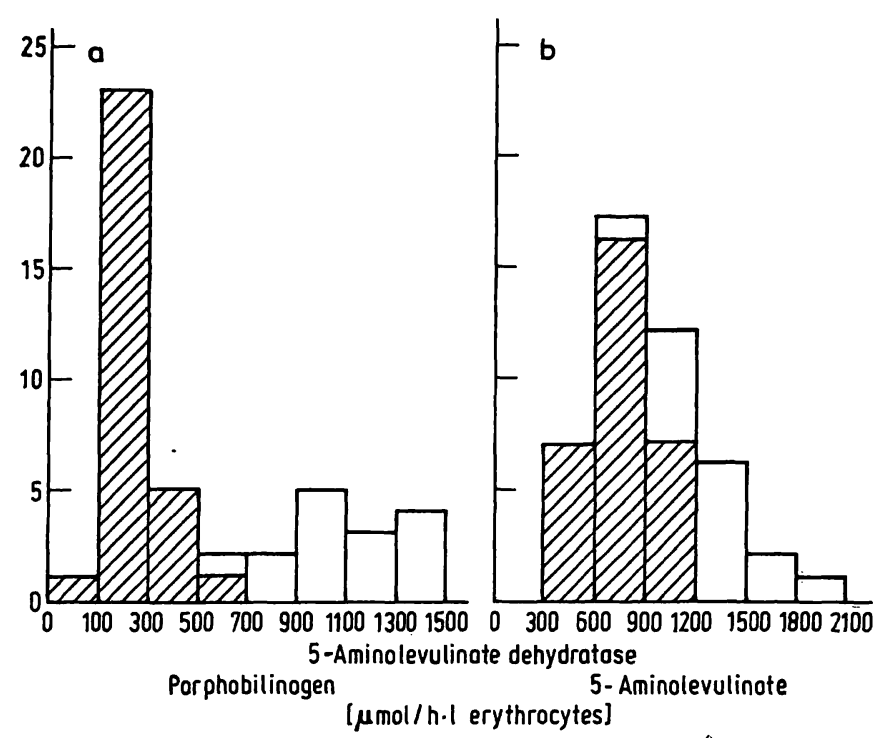

Fig. 5. Frequency distributions of activity of 5-aminolevulinate dehydratase estimated by method I (a) and method II (b). Values obtained for the control group and exposed workers represented by open and shaded areas, respectively.

(mean $=1090 \pm 250) \mu \mathrm{mol} / \mathrm{h} \cdot \mathrm{l}$. For exposed persons, these values ranged from 90 up to 550 (mean (porphobilinogen $)=250 \pm 120) \mu \mathrm{mol} / \mathrm{h} \cdot 1$ erythrocytes. The activity of 5-aminolevulinate dehydratase estimated according to method II ranged from 871 to 3074 (mean $=1715 \pm 590$ ) and from 339 up to 1278 (mean $(5$-aminolevulinate $)=758 \pm 244) \mu \mathrm{mol} / \mathrm{h} \cdot 1$ erythrocytes for the control and exposed groups, respectively.

\section{Discussion}

Berlin \& Schaller (15) prompted analytical chemists to adopt a standard European method for the estimation of the activity of 5-aminolevulinate dehydratase in blood. These authors emphasized also that the method proposed by them is suitable for the lead concentration range up to $1.93 \mu \mathrm{mol} / 1$ blood, corresponding to the usual level of environmental exposure to this metal. The range of lead concentrations on which the method of Tomokuni (14) is based is equal to $0-3.38 \mu \mathrm{mol} / 1$. Haas et al. (1) also used this lead concentration range.

In the present experiments, the blood lead concentration ranged from 0 to $11.60 \mu \mathrm{mol} / 1$ blood. The lower mean values of activity of 5-aminolevulinate dehydratase noted here for both the control and exposed groups, as compared with those found by Tomokuni (14), are due to high lead concentrations in blood. A high degree of inhibition of activity of 5-aminolevulinate dehydratase was revealed in more than $60 \%$ of the exposed persons, this activity being lowered by about $80 \%$ when estimated by the method of Tomokuni (14) and by only about $50 \%$ when estimated by the method of Berlin \& Schaller (15). This difference is probably due to different $\mathrm{pH}$ values of the incubation media in both methods $(14,15)$.

Moreover, when comparing these methods, higher values of the correlation coefficient between activity of 5-aminolevulinate dehydratase activity and lead concentration in blood were found for the method of Tomokuni (14) (table 1). For the lead concentration range up to $4.35 \mu \mathrm{mol} / 1$ blood the value of $\mathrm{r}=0.75$ obtained here is identical with the value reported by both Tomokuni \& Ogata (5) and Haas et al. (1).

These results indicate that both the method of Tomokuni (14) and the method of Berlin and Schaller (15) are suitable for determination of the activity of 5-aminolevulinate dehydratase in blood containing lead concentrations less than $4.35 \mu \mathrm{mol} / 1$. The high correlation coefficient $(r=0.82)$ and the regression equation enable the interconversion of results between these methods.

However the ratio of activities of 5-aminolevulinate acid dehydratase determined by method I and method II (expressed in the same units) depends on the blood lead concentration (tab. 2). The variable value of this ratio is a result of the chosen $\mathrm{pH}$ level for incubation of this enzyme. Together with the rise of concentration of lead in blood the activity of 5-aminolevulinate dehydratase decreases at $\mathrm{pH} 6.8$ (method I), and increases at $\mathrm{pH} 6.4$ (method II) (14).

However, when the lead concentration in the blood of exposed persons exceeds $4.35 \mu \mathrm{mol} / 1$, which results in a high inhibition of activity of 5-aminolevulinate dehydratase at $\mathrm{pH} 6.8$, only the method of Tomokuni (14) can be used for the estimation of the degree of exposure to lead, based on the 5-aminolevulinate dehydratase activity ratio. A high correlation coefficient $(r=0.80)$ was obtained for the activity ratio and the lead concentration in blood, in the range of the latter up to 11.60 $\mu \mathrm{mol} / 1$. A rationale for this may lie in the hypothesis of Tomokuni (14), that lead, changing the conformation of the molecule of 5-aminolevulinate dehydratase, also alters the $\mathrm{pH}$ dependence of the enzyme affinity for the substrate. The maximal activity of 5-aminolevulinate dehydratase in exposed persons occurs at $\mathrm{pH}$ 6.0, which is taken into consideration in the calculation of the activity ratio.

The present results suggest that method I (14) is more sensitive and gives a higher correlation coefficient between concentration of lead in blood and activity of 5-aminolevulinate dehydratase than method II (15). Moreover this method is more useful for the evaluation of a broad range of lead concentrations in the blood of exposed workers. 


\section{References}

1. Haas, Th., Mache, W., Schaller, K. H., Mache, K., Klavis, G. \& Stumpf, R. (1972), Int. Arch. Arbeitsmed. 30, 87-104.

2. Secchi, G. C. \& Alessio, L. (1974), Arch. Environ. Health. 29,351 .

3. Hernberg, S. (1976), in: Effects and dose-response relationship of toxic metals (Nordberg, G. F. ed.) Amsterdam Elsevier Scientific Publishing Company.

4. Bunneaux, F., Protin, P., Besson-Leaud, M. \& Fabioni, P. (1976), Eur. J. Toxicol. 9, 165-170.

5. Tomokuni, K. \& Ogata, M. (1976), Arch. Toxicol. 35, 239-246.

6. Alessio, L., Bertazzi, P. A., Toffoletto, F. \& Foa, V. (1976), Int. Arch. Occup. Environ. Health 37, 73.

7. Alessio, L., Bertazzi, P. A., Monelli, O. \& Foa, V. (1976), Int. Arch. Occup. Environ. Health 37, 89-105.

8. Alessio, L., Bertazzi, P. A., Monelli, O. \& Toffoletto, F. (1976), Int. Arch. Occup. Environ. Health 37, 177-186.
9. Kisser, W. (1977), Arch. Toxicol. 37, 173-193.

10. Lamola, A. A., Joselow, M. \& Yamane, T. (1975), Clin. Chem. 21, 93-97.

11. Piomelli, S. (1977), Clin. Chem. 23, 251-274.

12. Gibson, K. D., Neuberger, A. \& Scott, J. J. (1955), Biochem. J. 61, 618-629.

13. Bonsignore, D., Calissano, P. \& Cartasegna, C. (1965), Med. Lavoro 56, 199-205.

14. Tomokuni, K. (1974), Arch. Environ. Health 29, 274-281.

15. Berlin, A. \& Schaller, K. H. (1974), Z. Klin. Chem. Klin. Biochem. 12, 389-390.

16. Tomaszewski, L. (1970), Mikrometody biochemiczne w laboratorium klinicznym, Warszawa, PZWL.

17. Dutkiewicz, T., Piotrowski, J. K. \& Kȩsy-Dąbrowska, I. (1964), Chemiczne badanie materialu biologicznego w toksykologii przemyslowej, Warzawa, PZWL.

\section{Jadwiga Chmielnicka}

Institute of Environmental Research and Bioanalysis Medical Academy in Lọdź

Department of Toxicological Chemistry

ul. Narutowicza 120 a

PL-90-145 Lódź 
